\title{
Observations on the Resistance to Vertical Airflow of Green and Parchment Coffees
}

\author{
D. S. Boyce and A. A. Pérez-Fonrodona ${ }^{1}$
}

\section{INTRODUCTION}

The rational design of drying and conditioning units which are dependent on the flow of air through a granular product can be undertaken only if data are available concerning the resistance to airflow, that is, the static pressure which will result when a given quantity of air is forced through the material. Air is forced through a material either as a medium to remove moisture in drying or to remove heat in conditioning. Data on resistance to airflow are useful for determining either the power required to force a given volume of air through a known height of material, or secondly, if the fan characteristics are known, the volume of airflow can be determined for given conditions.

\section{REVIEW OF LITERATURE}

Data concerning the resistance to airflow of all the various important grains of commerce have been summarized by Shedd $(3) .{ }^{2}$ However, no such data seem to be available concerning parchment coffee and green coffee "beans." Eschenwald (1), however, observed a straight-line relationship when the static pressure in inches of water gage (in. w.g.) was plotted logarithmically versus the airflow for coffee fruit, and beans. In this case the word "beans" is believed to refer to parchment coffee.

\section{MATHEMATICAL RELATIONSHIPS}

The three variables to be considered with respect to resistance to airflow data are:

$P=$ pressure drop through a depth of material, inches of water gage

$L=$ depth of material or distance of vertical air movement through material, feet

$V=$ airflow rate, cubic feet of air per minute at atmospheric temperature per square feet of floor area

Several ways of showing the relationship between these variables have been proposed. The simplest relationship assumes that the pressure drop

1 Assistant Professors, Department of Agricultural Engineering and Department of Mechanical Engineering, respectively, College of Agriculture and Mechanic Arts, Mayagüez, P.R. The authors wish to acknowledge the generous help of Francisca Pons, Assistant Professor of Mathematics, Computing Center, in carrying out some of the calculations.

2 It alic numbers in parentheses refer to Literature Cited, p. 64. 
through the material is independent of the depth of the material and is expressed thus:

$$
P_{a v}=K_{1} V^{m_{1}} \text {. }
$$

where $P_{a v}=$ average pressure drop in water gage per feet depth of material $K_{1}$ and $m_{1}=$ constants

It is apparent that if equation [1] is plotted on logarithmic paper a straight line results; however, it has been observed when examining plotted data (3) for a considerable number of different seeds that there is a general tendency for the curves to be concave upwards. Consequently, it is incorrect to assume that expression [1] rigorously represents such data, nor, especially, should it be used to calculate values outside the range wherein the original data have been collected. It should be noted however, that expression [1] is the most usual to represent this type of data.

As already stated $P_{a v}$ is the average pressure drop per feet depth of material. This is not, however, an exact measure of the pressure drop for a given depth of material as has been conclusively shown. Henderson (2) and Shedd (3) have shown that there is a noticeable nonproportional increase in pressure drop depending upon the depth of the material. It is for this reason that when data of this type are being collected they should be taken at different depths.

A more complete expression showing the relationship between airflow, depth of material, and pressure drop is:

$$
P=K V^{m} L^{n}
$$

\section{$K, m$, and $n=$ constants}

Now expression [2] is open to the same objections as equation [1]. To account for this convexity, Henderson (2) suggested the following modification of expression [2]

$$
P=K V^{m^{k}} L^{n}
$$

where $k=$ a constant

However, he found that when working with shelled corn the results of expression [2], were accurate within 2 percent of the more complex expression [3]. As it would be complicated to calculate values for $k$, it was assumed that expression [2] represented the relationship between the variables sufficiently closely for practical considerations.

It was stated earlier that resistance to airflow data can be used in two ways, either as in expressions [1] and [2] for determining the pressure drop for given values of $V$ and $L$; or, secondly, it may be desirable to determine airflow, knowing the expected pressure drop and the height of material. 
The methods actually used to calculate the various constants in this study were the standard statistical methods for determining a multiple regression, the expressions and the data first being reduced to the linear logarithmic form of expression [4]. Thus:

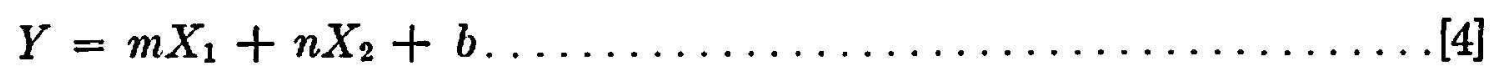

where $Y=\log _{10} 1,000 P^{3}$

$$
\begin{aligned}
& X_{1}=\log _{10} V \\
& X_{2}=\log _{10} L \\
& b=\log _{10} K
\end{aligned}
$$

It is, of course, necessary to calculate the regression of $P$ from $V$ and $L$ and then the regression of $V$ from $P$ and $L$. It is therefore, unlikely that the values obtained for the various constants would be the same as if a simple mathematical rearrangement of the terms had been made.

\section{EXPERIMENTAL PROCEDURE}

\section{APPARATUS}

To determine the resistance of airflow of a seedlike product a column of material must be arranged so that air can be forced through it in accurately controlled quantities. Shedd (4) investigated whether data obtained from bins (columns) with a small ratio of volume to area would be applicable to bins with a larger ratio. After extensive tests he determined that the effects of wall area were very small or negligible. A steel tube 12 inches in diameter and 9 feet in effective height was used for this investigation. The column was made in three flanged sections. At 1-foot intervals, commencing at the level of the column bottom, four equally spaced holes were drilled, and suitable fittings were welded into place. All the fittings at each height were interconnected with heavy rubber tubing to form a piezometer ring. Each piezometer ring was, in turn, connected through airtight valves to a manifold which could then be connected to a pressure-indicating instrument with a suitable range for measuring the pressure at the piezometer ring. Figure 1 shows a part of the column, the piezometer rings, the manifold, etc.

Two different types of pressure-indicating devices were used. Over 96 pereent of the pressure readings were made with a direct-reading micromanometer with a range of $0-;)$ inches water gage. This instrument, could be

a $P$ is multiplied by 1,000 to remove decimal points for convenient computation. 


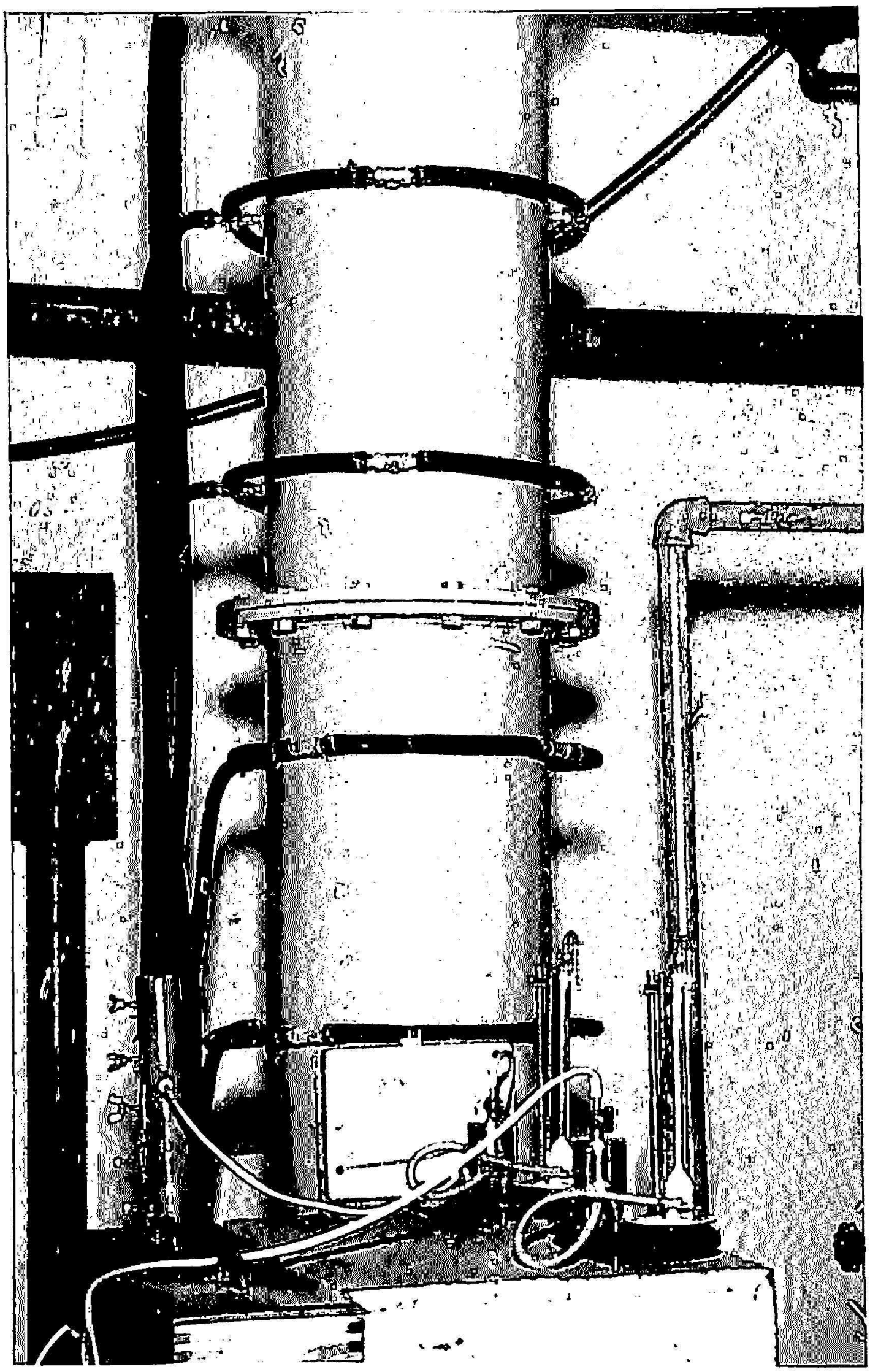

Fici. 1.-A part of the apparatus used to determine the resistance to airflow of parchment coffec and green coffee. A section of the column, the piczometer rings, the manifold, and 2 micromanometers are shown. 
directly read to one-thousandths and estimated to ten-thousandths of an inch. Repeat readings could be made with this instrument consistently to a hundredth of an inch and frequently to a thousandth. Readings exceeding 5 inches water gage were made with a standard U-tube manometer which could be read directly to a tenth of an inch and estimated to a hundredth.

Previous workers had used a number of different methods of obtaining the necessary airflow. Shedd (4) lowered an inverted cylinder into a tank of water displacing air at a constant rate. Henderson (2) used tanks of compressed air while Shedd (5) used a motor-driven fan. The most convenient source of air available for this investigation was the compressed-air system of the Mechanical Engineering Laboratory at the College of Agriculture and Mechanic Arts. It was utilized in the following way: The air pressure in the delivery system was reduced to about 20 pounds per square inch by allowing most of the air to escape to the atmosphere through a variable nozzle. The air supply to the column itself was controlled by a manually operated valve. It was found that there were practically no noticeable fluctuations in the airflow provided the pressure in the delivery system was maintained at the value given.

In order to prevent any contamination to the contents of the column from oil which might have been carried from the compressor a suitable cleaner was fixed into the air-delivery system. A cooling device was fitted in series with the air-cleaner. This was to ensure that the air was reduced to ambient temperature:

The flow of air to the column was measured by arranging with appropriate valves three proprietary rotameters with suitable ranges in parallel. After the air had passed through the rotameter it was directed to a plenum chamber beneath the column. The contents of the column were supported on a screen bottom which was fastened at the bottom of the plenum chamber. The column and plenum chamber were supported by brackets some distance above the floor. It was therefore, a simple matter to empty the column by removing the bottom of the plenum chamber.

\section{MATERIALS}

The two materials considered were parchment coffee and green coffee beans. Parchment coffee is produced by processing coffee by the "wet process". A parchment coffee consists of one of the so-called coffee "beans" of commerce, hereafter referred to as "green coffee", enclosed in a thin membrane called the "silver skin" and then in an outer parchmentlike shell. Some of the physical characteristics of the parchment coffee and the green coffee used in this work are shown in table 1.

It was not possible to determine the size distribution of the parchment coffee grains as no suitable combination of sieves were available. However, 
the size distribution of the green coffee beans by weight is given below: Screen No.t

Percenlage relained by weight

Retained by No. 20

11.50

Passed No. 20; retained by No. 18

67.90

Passed No. 18; retained by No. 16

14.20

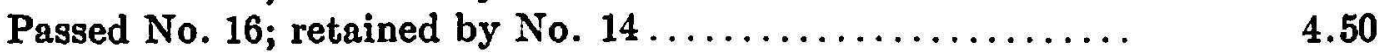

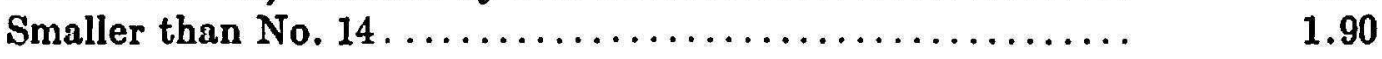

${ }^{1}$ Screen No. refers to openings of $1 / 64$ th inch.

\section{PROCEDURE}

The material was filled by gravity into the column and carefully leveled. No attempt was made to pack it or to investigate the effects of settling and so forth. The column was filled to a height of 9 feet with parchment coffee and with green coffee to 6 feet.

TABLE 1.-Physical characterislics of parchment coffee and green coffee beans used in the determination of resistance to airflow

\begin{tabular}{|c|c|c|}
\hline Characteristic & Parchment coffee & Green coffee \\
\hline $\begin{array}{l}\text { Bulk density } \ldots \ldots \ldots \ldots \ldots \ldots \ldots \text { lb. per cubic foot } \\
\text { Seed per cubic foot } \\
\text { Trash and broken material by weight........ percent } \\
\text { Moisture content, wet basis } \ldots \ldots \ldots \ldots \ldots \ldots \text { do. }\end{array}$ & $\begin{array}{r}28.80 \\
56,400 \\
2.70 \\
11.90\end{array}$ & $\begin{array}{r}36.95 \\
95,600 \\
4.70 \\
14.20\end{array}$ \\
\hline
\end{tabular}

For parchment coffee, static-pressure readings were made at 1-foot intervals commencing at the base of the column just level with the column floor and going up to 1 foot from the top. Readings were made from the base of the column to 2 feet from the top for green coffee.

Fourteen different airflow rates were used. It was thought that the range selected would be sufficiently broad to include most rates required for any likely drying or conditioning installation. They were as follows: 70.00 , $60.13,50.00,40.00,35.03,29.75,27.13,20.06,13.50,10.06,6.75,4.46,3.3$, and 1.15 cubic feet of air per minute per square feet of floor area.

Before actually starting to determine flow rates the column and the various parts which would be subjected to pressure were tested for leaks. It was assumed that if the column sealed at the top and related parts could retain an internal pressure of 10 inches water gage for 2 hours without a noticeable loss it would be satisfactory. No difficulties were encountered in fulfilling this requirement. After the data for parchment coffee had been obtained and before the column was filled with green coffee it was rechecked for leaks and was found to be again satisfactory. 
The following procedure was adopted for actually obtaining the pressure data: During the first run the air rates were progressively reduced from the highest to the lowest. The pressure at each piezometer ring was read for each air rate from the top to bottom. Then the readings were repeated in the opposite direction. When data for all the air rates had been obtained in duplicate the procedure was repeated.

Before each reading was made a steady airflow was obtained. The airflow rate was constantly checked to ensure that no variations occurred. Generally the airflow was found to be remarkably stable. In addition to pressure readings a record was kept of the temperature of the air entering the column. It was found to vary between $78^{\circ}$ and $81^{\circ} \mathrm{F}$., being generally in the range 79 to $80^{\circ} \mathrm{F}$. As the temperature variation was so small it was thought unnecessary to make any corrections for temperature.

\section{EXPERIMENTAL RESULTS}

Values for all the various constants associated with expressions [1] and [2] were obtained by first determining the logarithmic linear form of expression [4] using standard statistical methods for determining multiple regressions:

Expression [2] can then be written as follows:

For parchment coffee....P $=0.0010 V^{1.4612} L^{1.1604} \ldots \ldots \ldots \ldots \ldots[5]$

For green coffee........P $=0.0022 V^{1.3449} L^{1.2947}$

The multiple coefficient correlation was calculated for equations [5] and [6] in their linear logarithmic form and the value of $R$ was found to be in each case 0.99 .

Or, if it is desired to simplify expressions [5] and [6] in order to obtain an average value of $P$ per foot height of material, they can be written thus:

$$
\begin{aligned}
P a v & =0.0014 V^{1.46} \ldots \ldots \ldots \ldots \ldots \ldots \ldots \ldots \ldots \ldots \ldots \ldots \ldots \ldots \ldots \ldots \ldots \ldots \ldots \ldots \ldots \ldots \ldots \ldots \ldots \ldots \ldots \ldots \ldots \ldots \ldots
\end{aligned}
$$

If however, the value of $V$ is to be estimated from $P$ and $L$, the following expression should be used:

For parchment coffee. $\ldots \ldots \ldots V=\frac{91.51 P^{0.6557}}{L^{0.7667}} \ldots \ldots \ldots \ldots \ldots[7]$

For green coffee $\ldots \ldots \ldots \ldots \ldots V=\frac{90.54 P^{0.7275}}{L^{0.9418}} \ldots \ldots \ldots \ldots \ldots[8]$

If it is desired to simplify equations [7] and [8] so as to obtain an average 
value of $V$ for an average pressure drop per foot depth of material they can be written thus:

$$
\begin{aligned}
V a v & =72.00 P^{0.66} \ldots \ldots \ldots \ldots \ldots \ldots \ldots \ldots \ldots \ldots \ldots \ldots \ldots \ldots \ldots \ldots \ldots \ldots \ldots \ldots \ldots \ldots \ldots \ldots \ldots \ldots \ldots \ldots \ldots \ldots \ldots \ldots \ldots \ldots
\end{aligned}
$$

\section{DISCUSSION}

One of the most important questions about regression equations determined from data such as these is the confidence which can be placed in any estimate made from the regression. Different factors may affect the applicability of the equations. First, it must be considered whether the material used is truly representative and, secondly, it would be useful to know what variations would be expected between different lots of the same material with different, moisture contents, or trash contents, or between different varieties having somewhat different physical characteristics. It was not possible, however, to investigate these factors as it would have required an inordinate amount of time for all the necessary replications. It can be pointed out, however, that data obtained by other workers for seedlike products can be questioned to varying degrees on the same grounds. However, similar data for other like products have been found to be generally applicable, provided of course there is no considerable difference in physical characteristics.

Shedd ( 3 ) noted that moisture content, foreign material, and density could have a considerable and, at times, variable effect on resistance to airflow in the order of $\mathbf{2 5}$ to $\mathbf{7 5}$ percent. He noted, however, that, for any given grain, if airflow versus pressure data were plotted for different moisture or foreign material contents, or densities, the curves were substantially parallel. That is, the power constant to which either $P$ or $V$ is raised remains unchanged while only the value of $K$ changes. Therefore, suitable corrections can be made for any values of $P$ or $V$ which have been determined by multiplying them by a constant.

Shedd also pointed out that, if grain of a high moisture content is packed tightly into a drying bin, shrinkage will occur as drying progresses, with a general reduction in the tightness of the fill. Generally, he found that foreign material mixed with the grain tended to increase the resistance to airflow if the foreign material were finer than the grain and to reduce it if it were coarser. It can be concluded that there will be pressure variations between different batches of material and also within the same batch during different periods in the drying cycle. Therefore, resistance to airflow data can be used only as a general indicator, and variations must be expected. 
Physical factors which may cause variations in the resistance to airflow have been discussed. It is also useful to consider within what statistical limits expressions [5] and [6] may be used to determine on the average any value of $P$ within the 5-percent probability levels. Now, as the regressions were originally determined in the form of equation [4] no expression can be derived for expressing the standard error or any given value of $P$; however, the following expressions were determined for standard error $S y_{1.2}$ of $Y$, if it be assumed that all the originally observed pressure readings are independent of each other.

For parchment coffee....S.Sy $y_{1.2}=\left(0.0002 X_{1}{ }^{2}+0.0006 X_{2}{ }^{2}\right.$

$\left.+0.0001 X_{1} X_{2}-0.0006 X_{1}-0.0008 X_{2}+0.0006\right)^{1 / 2} \ldots \ldots \ldots \ldots[9]$

with 429 degrees of freedom.

For green coffee....S $y_{1.2}=\left(0.0001 X_{1}{ }^{2}+0.0013 X_{2}{ }^{2}\right.$

$\left.-0.0003 X_{1}-0.0015 X_{2}+0.0007\right)^{1 / 2} \ldots \ldots \ldots \ldots \ldots \ldots \ldots \ldots[10]$

with 277 degrees of freedom.

It should be noted that the $X_{1} X_{2}$ term is omitted from expression [10] as it had only a negligible value.

Knowing $S y_{1 \cdot 2}$ and selecting a suitable value of " $t$ ", fiducial limits for any value of $Y$ determined from values of $X_{1}$ and $X_{2}$ may be calculated, and the limit values for $Y$ can then be expressed in terms of $P$, and the percentage variation of $P$ determined. The value of $S y_{1.2}$ is, of course, variable, and is at its minimum at the mean value of $Y$ and increases with increasing or decreasing values of $Y$. The calculated variation of the mean value of $P$ for parchment coffee was 0.31 -inch water gage, with a variation of \pm 3.28 percent at the 0.05 -percent level. This variation increased to about \pm 5 percent towards the extremes of the data. A similar value for green coffee was a mean value of 0.51 -inch water gage with a \pm 2.69 -percent variation; as the limits of the data were approached the variation again increased to about \pm 5 percent. Though this variation is considerable, it is unlikely to exceed variations caused by differences in trash content, moisture content, etc. It should be noted that the variations associated with expressions $5 a$ and $6 a$ will be greater than those associated with the complete expression.

Should the pressure data be used as an estimate of airflow, similar expressions for determining the percentage variation can be determined. The actual expressions are not shown but the percentage variations will, of course, be of the same order for $V$ as for $P$, considering the very high correlation between the variables. 


\section{SUMMARY}

Resistance to airflow data for seedlike products is necessary if drying and conditioning units based on the flow of air through the material are to be rationally designed. No such data were available for parchment coffee and green coffee beans. Suitable equipment for determining such data was constructed and the necessary data from a representative batch of each material were collected. Mathematical expressions relating the variables were determined using standard statistical methods. While a number of factors are known to cause a considerable variation in airflow through a given material, this has in no way reduced the value of airflow data in relation to installations for other grainlike products. It is therefore felt that the data obtained may be useful as a guide for those concerned with the design and operation of dryers and conditioners for parchment coffee and green coffee.

\section{RESUMEN}

Para el diseño racional de unidades para el secado y acondicionamiento de granos o productos similares mediante ventilación por presión debe contarse con datos relativos a la resistencia que ofrecen estos productos al flujo del aire. No habiendo datos disponibles para el café pergamino ni para el café oro, se construyó equipo adecuado para determinar dichos datos los cuales se obtuvieron de una muestra representativa de cada material. Se determinaron las expresiones matemáticas con relación a las variables pertinentes mediante métodos estadísticos usuales. Aunque es sabido que hay un número de factores que causan variaciones considerables en el flujo del aire a través de un material determinado, esto en ningún modo ha disminuído el valor práctico de tales datos en relación a instalaciones para otros productos similares. Por lo tanto, puede confiarse en que los datos presentados sean de utilidad como guía de aquellas personas concernidas con el diseño y operación de instalaciones para el secado y acondicionamiento de café pergamino y café oro.

\section{LITERATURE CITED}

1. Eschenwald-Hess, A., Some Basic Properties of the Coffee Fruit and Coffee Bean, unpublished M.S. thesis, Michigan State University, 1959.

2. Henderson, S. M., Resistance of shelled corn and bin walls to airflow, Agr. Eng. 32 (9) 493-5, 1951.

3. Shedd, C. K., Resistance of grains and seeds to airflow, Agr. Eng. 34 (9) 616-9, 1953.

4. - Some data on the resistance of grain to airflow, Agr. Eng. 32 (9) 493-5, 1951.

5. - - Resistance of earn corn to airflow, Agr. Eng. 26 (1) 19-21, 1945. 